\title{
Sellar Chordoma
}

National Cancer Institute

\section{Source}

National Cancer Institute. Sellar Chordoma. NCI Thesaurus. Code C155781.

A chordoma that arises from the sellar region. 